\title{
Relationship between Consumer Acquisition Efforts and Consumer Loyalty
}

\author{
Jagwinder Singh ${ }^{1}$ and Shivani Saini ${ }^{2}$ \\ Department of Humanities and Management, Dr. B. R. Ambedkar National Institute of \\ Technology, Jalandhar, India \\ 1jagwinpandher@yahoo.com, ${ }^{2}$ inshivani_saini19@yahoo.com
}

\begin{abstract}
Consumer Relationship Management is an integrated approach to manage longterm consumer relationships by implementing the practices of right acquisition and retention efforts. The purpose of study is to examine the key role of consumer acquisition efforts in driving consumer loyalty through direct and indirect approaches. The empirical study has been conducted by taking a sample of 600 consumers from three diverse service categories, i.e. Health, Retail, and Wellness. In order to observe the service category as moderator, the present research aims to implement the multiple-group analysis in CFA and SEM through AMOS17.0. Results suggest that in health and wellness sectors, consumer acquisition efforts are positive enough to create behavioral loyalty only. No direct effect of consumer acquisition efforts on consumer loyalty has been reported across three service sectors. This paper empirically provides a detailed assessment of acquisition drivers that help a firm to build a loyal consumer base.
\end{abstract}

Keywords: Consumer Loyalty, Consumer Relationship Management, Consumer Acquisition Efforts, Trust, Commitment

\section{Introduction}

Every service firm is striving hard to search for sustainable competitive advantage. New market place is guiding the marketers to shift their focus from quality, cost, and technology-based competitive advantage to consumer-based advantage (Reichheld, 2003). The development, sustenance, and enhancement of consumer loyalty seem vital to service marketers. Loyal consumers are the most-important drivers of growth and profitability of a firm (Reichheld, 2003). Less price sensitivity, upsurge in spending patterns, positive revisit intentions, positive wordof-mouth publicity, resistance to other sellers' offers, understanding of future arising needs/wants, and low consumer acquisition costs are the significant benefits of consumer loyalty (Dick \& Basu, 1994; Jensen \& Hansen, 2006; Krishnamurthi \& Raj, 1991; Harris \& Goode, 2004; Ladhari et al., 2007; Peppers \& Rogers, 1993). 
Recently, marketers have shifted their emphasis from mass marketing to one-to-one marketing in order to manage long-term relationships with their consumers. Consumer Relationship Management (CRM) applications are both the manifestation and testimony of the fact that the organization is consumer-centric. The acquisition, retention, and development of consumers are three strategic activities of a CRM programme (Berry, 1995). CRM enables the firms to deploy strategies of acquisition, retention, and development for managing relationships with the support of computer databases (McKim \& Hughes, 2001). However, given that CRM plays an important role in managing long-term relationships with consumers, firms are still facing varied results in the execution of CRM systems (Smith \& Chang, 2010).

It is no surprise that loyalty formation is a complex process. There is hardly any empirical study that provides such deep insights into the process of loyalty development. However, it is very important to understand the mechanism of loyalty formation that involves the importance of different CRM components. The present study has been focused on acquisition component of CRM. The significance of this study is twofold. First, this study proposes the understanding of mechanism to develop consumer loyalty through acquisition efforts. The understanding of the mechanism to consumer loyalty has been proposed by direct and indirect modes. Under the indirect framework, this study has examined the effects of three significant mediators; consumer satisfaction, consumer trust, and consumer commitment on loyalty. Second, given the diversity of services of three major service industries, this research examines the extent to which consumer acquisition efforts differ across different service categories.

This article is organized as follows. First, previous conceptualizations of constructs with hypotheses have been presented. Then the objectives, methodology, results under Confirmatory Factor Analysis and Structural Equation Modeling have been presented followed by discussion. Further, managerial implications, limitations, future research directions, and conclusion have been outlined.

\section{Literature Review}

\subsection{Consumer Loyalty}

The concept of consumer loyalty has been developed over time. Early understanding of consumer loyalty in tangible goods category has coined the term brand loyalty (Cunningham, 1956; Jacoby \& Kyner, 1973) and lately its application in service sector advanced it to service loyalty (Gremler \& Brown, 1996). Broadly, the two thoughts, brand and service loyalty have been identified. And the consumer loyalty have been operationalized on the basis of behavioral and attitudinal components. 


\subsubsection{Behavioral Loyalty}

The primary focus of researchers for the measurement of consumer loyalty was on behavioral dimension. Behavioral loyalty represents a repeat purchase of product/brand over a period of time (Cunningham, 1956). The measurement of behavioral loyalty can be operationalized by examining consumer revisit frequency at a single firm (Ehrenberg, 1964), knowing switching intentions of a consumer (Javalgi \& Moberg, 1997), knowing consumer's revisit intentions (Trucker, 1964), the amount of consumer spending within specific product categories with a particular service provider, and consumers' sensitivity to situational factors (Mellens et al., 1996; Hart et al., 1999). However, behavioral dimension is unable to explain the reasons for consumer's repeat purchase. While it needs to be understood that consumer's repeat purchase can be constrained by many situational, individual, and socio-cultural factors (Oliver, 1999).

\subsubsection{Attitudinal Loyalty}

Many researchers have criticized the measurement of loyalty on behavioural basis and proposed an attitudinal dimension of loyalty. The attitudinal aspect of consumer loyalty has been developed to know the factors behind repeat behavior. The attitudinal aspect was focused to measure loyalty on the positive attitude of consumer towards a brand (Amine, 1998). The consumer's positive attitude has been defined to measure his/her psychological attachment and advocacy towards a firm (Chaudhuri \& Holbrook, 2001). The operationalization of attitudinal loyalty can be done by measuring consumer's understanding about the unique characteristics of a brand/firm (Jacoby \& Chestnet, 1978), consumer brand perception (Fishbein \& Ajzen, 1975), consumer's willingness for the recommendations, and positive word-of-mouth publicity (Rundle-Thiele, 2005; Zeithaml et al., 1996). The measurement under attitudinal loyalty was constrained by a consumer's willingness to provide information.

Some of the researchers such as Day, 1969 have opposed it, and subsequently the composite approach incorporating behavioural and attitudinal dimensions of consumer loyalty has been proposed (Jacoby, 1971; Dick \& Basu, 1994).

\subsection{Consumer Relationship Management}

The terms relationship marketing and consumer relationship management have been often used interchangeably and literature defines the consumer relationship management narrowly as a database marketing (Bickert, 1992), consumer retention (Vavra, 1992) whereas; many other researchers had focused on the broader aspect by stressing the need to maintain long term firm- consumer relationships (Berry, 
1995). In simple terms, CRM is all about developing an inclusive map of consumer needs/expectations/behavior and effectively managing those factors that affect the business performance. CRM can be defined as "A management approach that enables organizations to identify, attract, and increase retention of profitable customers, by managing relationships with them" (Bradshaw \& Brash, 2001). Parvatiyar and Sheth (2001) explain the strategic perspective of customer relationship management that has been defined as "a comprehensive strategy and process of acquiring, retaining, and partnering with select customers to create superior value for the company and the customer. It involves the integration of marketing, sales, customer service, and the supply-chain functions of the organization to achieve greater efficiencies and effectiveness in delivering customer value". To conclude; process, strategy, philosophy, capability, and technology are five important bases to understand the concept of CRM (Zablah et al., 2004).

Some approaches on the subject driven by technology advancements have produced a Kansei based value creation driven literature to understand consumer behavior (Kosaka \& Shizuka, 2009). Initially, CRM processes are targeted to use available databases to understand the consumer likness that help a firm to acquire, retain, and to keep loyal consumers (Greenberg, 2001). Consumers' perceptions differ with respect to availing of different types of services (Hsieh et al., 2005). In service contexts, consumers (patients in health care services) often face considerable uncertainty and inappropriateness stemming from factors such as language barriers, cultural differences, and operational processes (Lor \& George, 2013).

The strategic focus of CRM programmes is to build strong relational bonds (Osarenkhoe \& Bennani, 2007). Firms' have to be enthusiastic for the implementation of CRM programmes. The value of customer relationship changes with progress in their lifecycle stages. The starting point of managing the consumer lifecycle is consumer acquisition. A company's expansion plans and new product launches are always targeted to acquire new and profitable consumers. These efforts help a firm in the successful run of other processes of consumer lifecycle; consumer retention, and consumer development (Buttle, 2004). Thus to understand consumer expectations, CRM consists of a set of computer databases needs to be used with various business analysis tools. The technology advancements and growing number of competitors are raising the levels of consumer expectations. It encourages the firms to extend their product or service based offerings into creating memorable experiences. In other words, every consumer expects delightful unique experiences (Pine \& Gilmore, 1999). In all, acquisition, retention, and experience are three components of a CRM programme. In this paper, we are initializing to test the impact of merely consumer acquisition efforts on two forms of consumer loyalty. 


\subsubsection{Consumer Acquisition Management}

Consumer acquisition is one of the important processes of consumer management (Kaplan \& Norton, 1992). Consumer acquisition efforts are made to find the prospective consumers. The prospective consumers can be approached by various traditional and modern tools. Firms can use advertising, sale promotion, merchandising, and referral schemes to acquire new consumers. Advertising has been found to be the most important tool of consumer acquisition in businessconsumer contacts. The media coverage of new launches, telemarketing, emails, exhibitions, canvassing events can also be significantly used to contact new consumers (Buttle, 2004). The targeting management, consumer information management, production/service customization, expansion management, and referrals management are among the main processes of CRM. These processes are targeted to identify new and profitable consumers (Oztaysi et al., 2011). In service firms, customization processes are positive to build consumer loyalty and its impact on loyalty is magnified in the presence of consumer satisfaction and trust (Coelho \& Henseler, 2012). A firm's offerings based by management of physical-product settings, people, and processes differs across consumer groups (Ramanathan, 2011).

\subsection{CRM to CL}

CRM is a strategical approach that helps the firms to build strong relationships with their potential consumers (Osarenkhoe \& Bennani, 2007). Firms are advised to keep strong relational bonds with their consumers to maintain the level of satisfaction and loyalty (Mithas et al., 2005). The successful implementation of CRM programmes targets towards the achievement of goals of consumer satisfaction and loyalty (Ness et al., 2002). It is important for the organizations to build strong access of the running of CRM programmes. The unsuccessful rate of CRM processes has a negative effect on consumer satisfaction and loyalty (Richards \& Jones, 2008). The non-suitability of a single model for all the firms reinforces the development of customized CRM programmes for every single firm (Oztaysi et al., 2011). Sometimes time boundaries and human resource restrictions provide significant differences on delivery of desired service quality (Shankar et al., 2006). The technological perspective of CRM is enhancing the use of consumer data to make superior offerings and to make the right judgment about consumer lifecycle, retention, and loyalty (Greenberg, 2001). The e-CRM through operational, analytical, and collaborative is important to provide the customized solutions and to improve consumer satisfaction and loyalty levels (Dash \& Das, 2012). The offerings based on product/service quality help a firm in effective implementation of acquisition and retention strategies as well as to gain a loyal consumer base (Zineldin, 2006). The management of consumer acquisition, retention, and 
development activities are important for the successful businesses. Firms can use acquisition tools such as advertising, sales promotion, emails, SMSs, referrals, and several others in building a new consumer base. While consumer retention tools such as loyalty schemes, discounts, sales promotions, club memberships, and unique product/service offerings can be useful to decrease consumer defections and strengthen consumer lifecycle. Firms can retain their consumers for a long time by keeping their trust and commitment based attitude (Buttle, 2004).

\subsection{Mediators to Consumer Loyalty}

Many previous studies have suggested that satisfaction, trust, and commitment are the key ingredients of successful and meaningful relationships (Garbarino \& Johnson, 1999; Buttle, 2004; Kaur \& Soch, 2012; Sahin et al., 2011). Relationships evolve through various stages; awareness, exploration, expansion, commitment and dissolution. Satisfaction arises at exploration stage where two dyadic parties perform as per expectations of each other. Trust develops on expansion where both parties found to be dependent on each other. Simultaneously, commitment generates with time when both parties mutually cooperate to continue their relationships (Buttle, 2004). The available literature is making distinct and ambiguous contributions regarding the mediators of consumer loyalty, thus we propose the idea of collective testing of mediators between proposed relationships. To consider the relative impact of satisfaction, trust, and commitment on consumer loyalty, we propose these constructs as mediators in the link of consumer acquisition efforts and consumer loyalty.

\subsubsection{Satisfaction}

The consumer's satisfaction with a firm can be explained both on cognitive and affective measures (Roest \& Peters, 1997). Cognitive base of satisfaction is based on firm performances on service terms (Danaher \& Haddrell, 1996) while affective base targets on emotional bonding of consumers with a firm or firm's representatives (Wrestbook \& Oliver, 1991). Marketing practitioners have defined cognitive and affective basis of satisfaction by single dealing or overall perspectives. In 1980s, Oliver defined satisfaction as a function of a cognitive comparison of expectations prior to consumption with the actual experience. Lately in 1993, Oliver has defined satisfaction on the basis of transaction perspective as an affective reaction to the most recent experience with a firm. The cumulative aspect of satisfaction is an overall evaluation based on the total purchase and consumption experience with a product or service over time (Anderson et al., 1994). The importance of cognitive and affective aspects of behaviour has been emphasized in the overall construct (Yu \& Dean, 2001). The overall satisfaction is superior to transaction construct. It is also the major driver of business growth and consumer 
loyalty (Fornell et al., 1996). Overall satisfaction increases consumer's behavioural loyalty (Jones \& Suh, 2000).

\subsubsection{Satisfaction as a mediator in CRM and CL link}

As with consumer loyalty, consumer satisfaction is also influenced by CRM practices. To authors such as Yannis et al. (2014), satisfaction appears to be a new way for improving logistics service quality of some firms. Delivering right service quality leads to consumer satisfaction and ultimately consumer loyalty (Vasumathi \& Subashini, 2015; Kabiraj \& Uniyal, 2013). Consumer satisfaction with service quality is a competitive advantage for the service industry (Hsieh \& Yeh, 2015). Firms are motivated to keep strong relational bonds with their consumers to maintain the level of satisfaction (Mithas et al., 2005). The impact of satisfaction on loyalty is more significant in a business environment where firms' are offering less differentiated products and facing low switching costs (Jones \& Sasser, 1995). Numerous studies in marketing literature have hypothesized and empirically tested the relationship between both (cognitive and affective) aspects of satisfaction and consumer loyalty (Colgate \& Stewart 1998; Hocutt, 1998; Lai et al., 2009; Gerpott et al., 2001; Yu \& Dean, 2001).

\subsubsection{Trust}

The development of a successful relationship between a consumer and service firm is based on trust component (Morgan \& Hunt, 1994). Trust is time based concept that develops over time (Delgado-Ballester \& Munuera-Alemen, 2001). Trust can be defined as "a willingness to rely on an exchange partner in whom one has confidence" (Moornam et al., 1993). Another definition signifies trust as "a perception of confidence is exchange partner reliability and integrity" (Morgan \& Hunt, 1994). In the marketing literature, confidence (Moornam et al., 1993), reliability (Morgan \& Hunt, 1994) and positive future intentions (Garbarino \& Johnson, 1999) are three basic fundamentals of trust. The positive links between trust and consumer's future buying intentions has been empirically proved in previous researches (Garbarino \& Johnson, 1999; Ndubisi, 2007).

\subsubsection{Trust as mediator in the CRM and CL link}

To manage the long-term consumer relationships, firms should extend their satisfaction programmes with some reliable activities to build brand trust (DelgadoBallester \& Munuera-Alemen, 2001). It can be enhanced by providing positive experiences to consumers at the time of search, shop, and consumption. Firms' efforts to deliver positive and memorable brand experiences develop consumer's trust (Sahin et al., 2011). Consumers' trust on brand has a significant effect on 
brand loyalty (Delgado-Ballester \& Munuera-Alemen, 2001). The positive links between trust and consumer's future buying intentions have been empirically proven in previous researches (Garbarino \& Johnson, 1999; Ndubisi, 2007). In other words, trust is important in building strong consumer relationships and has a positive impact on consumer loyalty towards a brand (Chaudhuri \& Holbrook, 2001, Morgun \& Hunt, 1994, Moornam et al., 1993).

\subsubsection{Commitment}

Commitment is recognized as an essential variable in consumer-service provider relationships (Morgan \& Hunt, 1994). The stability of a firm-client relationship depends upon the consumers' commitment to a firm (Wang et al., 2004); and in service conditions, it works positively to gain consumer loyalty (Moornam et al., 1993). Commitment can be defined as "an enduring desire to maintain a valued relationship" (Moornam et al., 1993). It is a multi-dimensional concept (Fullerton, 2003) and includes two broad components; affective and calculative. The affective component represents consumer's emotional attachment with a service or brand on ideal image philosophy (Allen \& Meyer, 1990). While the calculative aspect signifies consumer's cognitive constraint based binding with a firm, which might be based on either high switching costs or scarcity of the best alternatives (Wetzels et al., 1998; Bendapudi \& Berry, 1997). Both forms of commitment found to have a positive impact on consumer-service provider relationships and consumer loyalty. The affective component in comparison to calculative has a strong positive impact on attitudinal loyalty (Fullerton, 2003).

\subsubsection{Commitment as a mediator in the CRM and CL link}

Firms implementing CRM may see it as a way to have committed consumers. Commitment has been found as an important phase of the relationship process (Buttle, 2004). Committed consumers often ignore their dissatisfaction with a preferred seller in order to maintain long-term relationships (Wu, 2011). In other words, consumer's commitment is a strong determinant of consumer loyalty. Committed consumers are more likely to remain loyal to the service firm as they feel that the service relationship is important. As a result, they have a desire to sustain the relationship while also being willing to put maximum efforts into continuing the relationship. Many previous studies suggest that there is a positive relationship between commitment and consumer loyalty (Fullterton, 2005; Bendapudi \& Berry, 1997; Brown et al., 2005; Morgan \& Hunt, 1994).

All the above discussed constructs have been framed in independent and dependent framework in structural model and supported with extensive review of literature. 


\section{Objectives and Hypotheses of the Study}

Based on the earlier work in the literature, this study proposes (1) to investigate the direct and indirect impact of consumer acquisition efforts on consumer loyalty (2) to explore various acquisition drivers that help a firm to build consumer loyalty. Figure 1 exhibits the research model that guides this research. Overall, based on the literature discussed above, this study develops a framework linking acquisition efforts and three mediators to two forms of consumer loyalty; attitudinal loyalty and behavioral loyalty (Refer figure 01), and the following hypotheses have been developed:

H1: The firm's consumer acquisition efforts have a positive effect on satisfaction.

H2: The firm's consumer acquisition efforts have a positive effect on trust.

H3: The firm's consumer acquisition efforts have a positive effect on commitment.

H4: Satisfaction has a positive effect on attitudinal loyalty.

H5: Satisfaction has a positive effect on behavioral loyalty.

H6: Trust has a positive effect on attitudinal loyalty.

H7: Trust has a positive effect on behavioral loyalty.

H8: Commitment has a positive effect on attitudinal loyalty.

H9: Commitment has a positive effect on behavioral loyalty.

H10: The firm's consumer acquisition efforts have direct and positive effect on attitudinal loyalty.

H11: The firm's consumer acquisition efforts have direct and positive effect on behavioral loyalty.

\section{Methods}

\subsection{Data Collection and Sample}

Three service types have been chosen to test the hypotheses: Health (Health Clinics and Hospitals), Retail (Convenience Stores), and Wellness (Beauty Salons and Gym/Fitness Centers). A sample of 200 consumers under the each service type has been collected. Over a three month schedule, a sample comprising of 600 consumers has been drawn from the five major cities (Amritsar, Ludhiana, Jalandhar, Patiala, and Chandigarh) in the northern region of India. Both random and judgment sampling techniques have been used to select the sample at the service provider's premises. A common questionnaire (including multi-item statements and demographic information) has been designed for the consumer 
survey. The scale has been derived from extensive literature reviews followed by a pilot study. The demographic profile of the sample is shown in table 1. (Refer table 01).

\subsection{Measures}

There are six theoretical constructs used in this study: consumer acquisition efforts, satisfaction, trust, commitment, attitudinal loyalty, and behavioral loyalty. All the constructs have been assessed by multi-items and a 7-point scale from 1-strongly disagree to 7 -strongly agree. The chosen constructs have been adapted and modified from the extensive review of literature (Ehrenberg, 1964; Javalgi \& Moberg, 1997; Trucker, 1964; Mellens et al., 1996; Hart et al., 1999; Jacoby \& Chestnet, 1978; Fishbein \& Ajzen, 1975; Rundle-Thiele, 2005; Zeithmal et al., 1996; Buttle, 2004; Oztaysi et al., 2011; Verheof et al., 2009; Morgan \& Hunt, 1994; Anderson \& Weitz, 1992; Wetzels et al., 1998; Bendapudi \& Berry, 1997). The constructs and their constituents with codes have been shown in table 2. (Refer table 02).

\subsection{Reliability and Validity}

The measures used in the study are subject to Confirmatory Factor Analysis (CFA) and Structural Equation Modeling (SEM). The reliability of measurement items has been tested by cronbach alpha $(\alpha)$ and composite reliability. The insignificant items have been excluded in the testing of reliability and validity. The value of ' $\alpha$ ' has been accepted by 0.7 to 0.9 (Roberts \& Wortzel, 1979) while composite reliability has been accepted by 0.7 or above (Hair et al., 1998). The constructs for all selected service categories support the convergent and discriminant validity. To test the convergent validity, average variance extracted (AVE) of all constructs has been found above 0.5 (Fornell \& Larcker, 1981). The squared correlations of all constructs in three service categories have been found less than their respective AVE values to establish the discriminant validity (Fornell \& Larcker, 1981). Table 3 provides the cronbach alpha $(\alpha)$, composite reliability, and AVE results. (Refer table 03).

\section{Findings}

The presentation of results has been done into two subsections. First, the measurement model (CFA) has been discussed to access the reliability and validity of proposed constructs. Subsequently, SEM results have been presented to test the relationship between proposed constructs. Both the models have been tested through multiple-group analysis (service category as moderator) using AMOS 17.0. The multiple-group analysis has been used to test the invariance (equal weights) among the samples across three service sectors. 


\subsection{CFA Results}

The proposed constructs with significant and insignificant items have been shown in table 2. The significance of one item to another has been assessed by comparing their respective values. The loadings of most of the indicators are positive and above/approximate to the recommended limit (i.e. 0.4, Bagozzi \& Baumgartner, 1994). The insignificant items have been presented to limit the managerial actions in respective sectors. In the health sector, all the items have been significant except items labeled; advertisement reliability (CA7) and continuance commitment (C2). The retail sector also reported with positive and significant items except advertisement reliability (CA7), skilled \& expertizes services (CA12), contact by recommendations (CA13), contact by automated/ manual calls (CA15), and continuance commitment (C2). In wellness sector, all items have been reported significant except advertisement reliability (CA7), contact by awareness camps (CA11), and contact by automated/ manual calls (CA15).

\subsection{SEM Results}

Having the reliability and validity of the proposed constructs in the measurement model, an empirical structural model has been developed and tested in multiplegroup analysis by taking three sub-samples (Health, Retail, and Wellness). The results of three sub-samples have been compared under four constraint models (base, equal loading, structural covariance, and measurement residuals). The base model indicates that all three models are independent of one another. Subsequently, the equal loading model has been tested to compare regression weights across three samples. Afterwards, in the third model, constraints have been added to the previous model to test the equality of structural path weights. Finally, the fourth model has been proposed with testing of equal variances between indicator variables besides previous added constraints. These models have been compared on the basis of following tests.

First, Chi-square difference test has been used to accept service category as moderator. As evident from table 5, Chi-square difference between the models for second, third and fourth have been found insignificant. Second, in comparison to all constraint models base model has been reported with less RMSEA value i.e. 0.037. It indicates that the base model is perfect to choose among all the models. The model fit indices of base model are accepted by Bunch, 2008. (Refer table 04).

The structural relationships between latent constructs have been reported with variance in their regression weights. The results of hypotheses testing of this proposed model have been shown in table 5. The hypothesized path from consumer acquisition efforts to satisfaction has been significant in all three sectors (H1). 
While no significant effects have been found for consumer acquisition efforts to trust (H2) and consumer acquisition efforts to commitment (H3) paths in all three service categories. The H5 (satisfaction to behavioral loyalty) has been accepted in health and wellness sectors only. The linkage of satisfaction to attitudinal loyalty, and trust to behavioral loyalty have been found to be insignificant in all three sectors. Therefore, $\mathrm{H} 4$ and $\mathrm{H} 7$ have been rejected. While, trust has a positive and significant effect on attitudinal loyalty across three services. Thus, H6 has been accepted. As expected, commitment has positive effect on both forms of consumer loyalty; attitudinal and behavioral loyalty. Thus $\mathrm{H} 8$ and $\mathrm{H} 9$ have been accepted. Finally, the direct path between consumer acquisition efforts and both forms of consumer loyalty have been tested and found insignificant in all three sectors. Thus $\mathrm{H} 10$ and H11 have been rejected. The insignificant results of consumer acquisition efforts to consumer loyalty found to be inappropriate to perform mediation analysis (Hair et al., 1998). Thus the impact of mediators on two latent constructs (attitudinal and behavioral loyalty) has been comprehended through path analysis. The structural model with significant and insignificant hypotheses has been presented in figure 2. (Refer table 05 and figure 02).

\section{Discussion}

The study results have important contributions to the consumer loyalty and consumer relationship management literature. The results have primarily enlightened the role of consumer acquisition efforts towards consumer loyalty and its mediators. The key drivers that help a firm to build different forms of consumer loyalty have been explored.

Based on the SEM model results, the consumer acquisition efforts have been found to significantly affect consumer's satisfaction, whereas; no significant impact has been found on two other mediators; trust and commitment. No significant evidence has been reported to support the direct influence of consumer acquisition efforts on any of the two forms of consumer loyalty; behavioral and attitudinal loyalty. The strategies under acquisition efforts are significant to get consumer's cognitive, affective, and overall satisfaction. In health and wellness sectors, satisfaction has mediated the impact of consumer acquisition efforts on consumer loyalty, but it has been limited to behavioral loyalty and no positive impact on attitudinal loyalty has been observed. This implies that a firm's consumer acquisition strategies are worth to develop only behavioral loyalty through satisfaction. These results are in conformance to previous studies by Anderson et al. (1994) and Jones \& Suh (2000). This implies that consumers can be satisfied, and they can prefer to stay with the same firm, but their dealings with other sellers in near future cannot be ruled out due to lack of attitudinal loyalty. Their preference to other sellers can be forced by 
situational factors (location inaccessibility, attractive competitor's offers), individual factors (convenience) and socio-cultural factors (influence of social groups) (Oliver, 1999).

However, in the retail sector, no significant evidence has been found to support the direct effect of consumer's satisfaction even on behavioral loyalty. Therefore, all the significant consumer acquisition items are found to build consumer satisfaction only. These findings might be constructed as such that retail consumers tend to buy standardized products and these products can be bought at any nearby retail shops.

For all service categories, trust has shown positive impact only on attitudinal loyalty, whereas; commitment has a direct impact on both forms of consumer loyalty. So commitment is the only effective tool to gain both behavioral and attitudinal loyalty of consumers. Consumer acquisition efforts are not sufficient enough to produce trust and commitment in the consumer's mind and thus, fail to develop attitudinal loyalty in specific. But these are significant to initiate relationships with prospective consumers and satisfying them.

The study findings reject Indian marketers' misconception about consumer loyalty. The study results actually make them aware that their efforts to acquire new consumers can fetch consumer satisfaction only. However, consumer satisfaction can't ensure true consumer loyalty. The research findings are guiding marketers to develop commitment based relationships which might be not possible to be cultivated by relying on acquisition efforts only. So if they expect to ensure consumer loyalty, they need to focus more on trust and commitment based relationship with their once acquired consumers. However, trust and commitment determinants need to be explored and recognize more efficiently. The insignificant direct effect of consumer acquisition efforts on consumer loyalty in another way acknowledges the role of antecedents (satisfaction, trust, and commitment) in generating consumer loyalty. Numerous studies in the marketing literature have supported the satisfaction (Jones \& Sasser, 1995; Lai et al, 2009; Gerpott et al., 2001; Yu \& Dean, 2001), trust (Morgun \& Hunt, 1994; Moornam et al., 1993), and commitment (Brown et al., 2005; Morgan \& Hunt, 1994) as antecedents of consumer loyalty.

The drivers to acquire new consumers vary across health, retail, and wellness service types. In health and wellness sectors, these are positive to build consumer loyalty through satisfaction, while in retail; these are significant to develop satisfaction only. The ranking of these drivers differs across the three service sectors. In the health sector; service quality, nearby locations, customized services, and well-known image have been considered as the best acquisition efforts. In the 
retail sector; service quality, reasonable price, wide-variety, and price discounts/other benefits have been reported superior for the measurement of acquisition efforts. In wellness sector; customized services, service quality, wellknown image, wide-variety, nearby locations, reasonable price, and contact by recommendations have been considered the best efforts for acquiring new consumers. The results show conformity to earlier revelations that consumer behavior varies across service types (Hsieh et al., 2005; Ramanathan, 2011).

Service quality has been found to be the dominant factor for consumer acquisition of all three service types. Nearby locations, customized services, and well-known image have also been important drivers for all service types except retail. The rationale for locational preference might be that health and wellness services need more time investment and time pressed consumers prefer to visit nearby locations to save their time. In addition, service customization (convenient timings, assortment of services in package promotions, and preference to specific service staff) is more meaningful to health and wellness categories than retail (selling standardized products). Health and wellness services are difficult to evaluate before the purchase, so consumers prefer to depend on strong and socially acceptable brands for new connections. The next dominant factor for retail and wellness sector is wide-variety. This might be due to the fact that health services are more of a specialized nature whereas; retail and wellness services may be best delivered with extended lines of services/brands/products. The results show that reasonable price and price discounts/other benefits are dominant factors of consumer acquisition for retail consumers only. The underlying rationale is that retail consumers often make price comparisons of standardized products and prefer to attach those who offer them lower prices. Lastly, an effort to contact new consumers by recommendations has been important in the wellness sector only. One probable reason is that in comparison to health, wellness consumers may perceive minimal risk to contact newer firms for trial purposes and in retail, contact by recommendation does not have any merit.

This study also suggests some insignificant factors of consumer acquisition efforts. These factors may guide managers to resist their investment for several activities. First, for all service firms advertisements didn't find to be reliable source to contact new sellers. It might increase the customer tendency to ignore some sellers. Second, firms' effort to contact new consumers by organizing camps has been found insignificant for wellness consumers. It implies that wellness consumers are conservative to recognize new sellers. Third, skilled \& expertized services and contact by recommendations have been overlooked by retail consumers. It may be probably because that retail services are more affected by the product availability 
than expertise and recommendation services. Finally, retail and wellness firms are advised to resist calling new consumers by automated and manual processes. It indicates that service consumers find themselves inconvenient to receive any calls except in emergency or health related services Therefore; managers of service firms should identify merit of various efforts to acquire new consumers that may play important role in building consumer loyalty.

The present study has important implications for the practices of marketing. Consumer acquisition practices promote successful implementation of marketingmix tools. Marketing-mix tools can help a firm to design various marketing strategies to acquire new consumers. These are more evidently emphasis on creating competitive advantage to work positively for creating value propositions. Firms' efforts to acquire new consumers by delivering desired value propositions increase consumer satisfaction with a firm. Consumer satisfaction is a leading indicator of consumer revisits and positive repurchase intentions. In another way, successful consumer acquisition efforts help a firm to reduce the number of unhappy consumers. Not only is it the mode to avoid consumer unhappiness; it is a key point of differentiation to build a satisfied new consumer base to generate consumer loyalty. Although the effects of consumer acquisition efforts differ across service sectors in Indian market, thus the thorough study about consumers' perception and expectations towards service provider is essential.

Marketers of service firms should start their CRM process with consumer acquisition efforts. Consumer acquisition efforts are significant to attract new consumers and maintain a strong behavioral loyal consumer base. Managers should be aware that although the acquisition efforts are accepted by consumers, yet these are not sufficient enough to build and sustain true loyalty. Most importantly, commitment has greater ability to generate true consumer loyalty. Oliver (1999) definition of brand loyalty has also emphasized the importance of commitment in developing consumer loyalty. Therefore, managers need to convert merely satisfaction based loyalty to commitment based loyalty. Managers should cautiously invest in various acquisition efforts because every effort needs to justify its investment in terms of gaining the satisfied and loyal consumer base.

A firm's promotions by advertisements (in health, retail, and wellness sectors), organizing of awareness camps (in wellness), skilled \& expertize employees (in retail), referral schemes (in retail) and contact by automated/manual calls (in retail and wellness) have been discouraged to use for consumer acquisition. In some industries, consumer acquisition efforts might insufficient to develop even behavioral loyalty, but positively direct a firm to get a satisfied consumer base. Satisfied consumers provide a significant base for a service firm to initiate other 
processes of CRM i.e. retention efforts like loyalty programmes, cross-selling, upselling, one-to-one marketing, and experience management.

This study is not free of limitations. First, the research findings did not report the key determinants of trust and commitment, and their contributions to different forms of consumer loyalty. So, the further research is needed to explore the key drivers of trust and commitment. Also, this study took place within a specific geographic area with restricted service categories on a limited sample. Future research is suggested for the purpose of cross-validation with large sample sizes and accessing to a wide range of services. Large sample size would be desirable to have increased precision to estimate the true relationships. Finally, the effects of consumer demographics such as age, gender, and income have not been considered. Therefore, the study can also be extended to see the effects of various demographic variables on the contribution of different consumer acquisition efforts.

\section{Conclusion}

Research findings indicated that impact of consumer acquisition efforts on consumer loyalty differs across the three services. In health and wellness services, consumer acquisition efforts are significant to create partial consumer loyalty (behavioral loyalty) through satisfaction only. It indicates that satisfaction is a leading indicator of consumer revisits and positive repurchase intentions. However, in retail services, consumer acquisition efforts are positive to create satisfaction, but no significant effect of satisfaction on consumer loyalty has been reported. Managers should be aware that although the acquisition efforts are accepted by consumers, yet these are not sufficient enough to build and sustain true consumer loyalty. Most importantly, commitment has greater ability to generate true consumer loyalty. Oliver (1999) definition of brand loyalty has also emphasized the importance of commitment in developing consumer loyalty. Therefore, managers need to convert merely satisfaction based loyalty to commitment based loyalty. Managers should cautiously invest in various acquisition efforts because every effort needs to justify its investment in terms of gaining the committed loyal consumer base.

\section{References}

Allen, N. J. \& Meyer, J. P. (1990). The measurement and antecedents of affective continuance and normative commitment to the organization. Journal of Occupational Psychology, 63, 1-18. doi: http://dx.doi.org/10.1111/j.2044-8325.1990.tb00506.x

Amine, A. (1998). Consumers' True Brand Loyalty: the central role of commitment. Journal of Strategic Marketing, 6(4), 305-319, doi: http://dx.doi.org/10.1080/096525498346577 
Anderson, E., Claes, F. \& Lehman, D. (1994, July). Customer satisfaction, market share and profitability: findings from Sweden. Journal of Marketing, 58(3), 53-66. doi: http://dx.doi.org/10.2307/1252310

Anderson, E., \& Weitz, B. (1992, February). The use of pledges to build and sustain commitment in distribution channels. Journal of Marketing Research, 29(1), 18-34. doi: $10.2307 / 3172490$

Bagozzi, R. P., \& Baumgartner, H. (1994). The evaluation of structural equation models and hypothesis testing. In R. P. Bagozzi (Ed.) Principles of Marketing Research, (pg. 386-422). MA: Blackwell: Cambridge.

Bendapudi., N. \& Berry, L. (1997). Customers' motivations for maintaining relationships with service providers. Journal of Retailing, 73(1), 15-37. doi: http://dx.doi.org/10.1016/S0022-4359(97)90013-0

Berry, L. (1995). Relationship marketing of services growing interest-emerging perspectives. Journal of Academy of Marketing Science, 23(4), 236-245. doi: http://dx.doi.org/10.1177/009207039502300402

Bradshaw, D. \& Brash, C. (2001). Management customer relationships in the e-business world: how to personalize computer relationships for increased profitability. International Journal of Retail \& Distribution Management, 29(12), 520-530. doi: http://dx.doi.org/10.1108/09590550110696969

Brown, T. J., Barry, T. E., Dacin, P. A., \& Gunst, R.F. (2005). Spreading the word: investigating antecedents of consumer positive word-of mouth intentions and behaviors in retailing context. Journal of Academy of Marketing Science, 18(1), 4349. doi: http://dx.doi.org/10.1177/0092070304268417

Bunch, Niels. J. (2008). Introduction to Structural Equation Modelling: Using SPSS and AMOS. London: Sage Publications Ltd.

Buttle, F. (2004). Customer Relationship Management: Concepts and Tools. Oxford: Elsevier Butterworth Heinemann.

Chaudhuri, A., \& Holbrook, M.B. (2001, April). The chain of effects from brand trust and brand affect to brand performance: The role of brand loyalty. Journal of Marketing, 65(2), 81-93. doi: http://dx.doi.org/10.1509/jmkg.65.2.81.18255

Coelho, S. P., \& Henseler, J. (2012). Creating customer loyalty through service customization. European Journal of Marketing, 46(3), 331-356. doi: http://dx.doi.org/10.1108/03090561211202503

Colgate, M. \& Stewart, K. (1998). The Challenge of relationship in services: a New Zealand study. International Journal of Service Industry Management, 9(5), 454-468. doi: http://dx.doi.org/10.1108/09564239810238857

Cunningham, R. (1956). Brand loyalty- what where how much? Harvard Business Review, 34(1), 116-128. 
Delgado-Ballester, E. and Munuera-Alemen, J. (2001). Brand trust in the context of consumer loyalty. European Journal of Marketing, 3(11/12), 1238-1258. doi: http://dx.doi.org/10.1108/eum0000000006475

Danaher, P. \& Haddrell, V. (1996). A comparison of question scales used for measuring customer satisfaction. International Journal of Service Industry Management, 7(4), 4-26. doi: http://dx.doi.org/10.1108/09564239610129922

Dash, B. \& Das, S. (2012). Serving the customer. Indian Management, 51(3), 110-116.

Day, G. (1969). A two dimensional concept of brand loyalty. Journal of Advertising Research, 9 (3), 29-35.

Dick, A.S., \& Basu, K. (1994). Customer loyalty: toward an integrated conceptual framework. Journal of Academy of Marketing Science, 22(2), 99-113. doi: http://dx.doi.org/10.1177/0092070394222001

Ehrenberg, A.S.C. (1964). Estimation the proportion of loyal buyer. Journal of Marketing Research, 1(1), 56-59. doi: http://dx.doi.org/10.2307/3150321

Fishbein, M. \& Ajzen, I. (1975). Belief, Attitude, Intention and Behaviour: An Introduction to Theory and Research. Reading: Addison-Wesley.

Fornell, C., Michael, D., Eugene, W., Jaesung, C., \& Barbara, E. (1996). The American customer satisfaction index: nature, purpose and findings. Journal of Marketing, 60(4), 7-18.

doi: http://dx. doi.org/10.2307/1251898

Fornell, C. \& Larcker, D.F. (1981). Evaluating structural equation models with unobservable variables and measurement error. Journal of Marketing Research, 18(1), 39-50. doi: http://dx.doi.org/10.2307/3151312

Fullerton, G. (2003). When Does Commitment Lead to Loyalty? Journal of Service Research, 5(4), 334-344. doi: http://dx.doi.org/10.1177/1094670503005004005

Gerpott, T.J., Rams, W., \& Schindler, A. (2001). Customer retention, loyalty, and satisfaction in the German mobile cellular telecommunications market. Telecommunications Policy, 25(4), 249-269. doi: http://dx.doi.org/10.1016/S03085961(00)00097-5

Greenberg, P. (2001). CRM at the Speed of Light, Berkley. CA: McGraw-Hill,

Hair, Jospeh F. Jr., Anderson, Rolph., Tatham, Ronald L., \& William, Black C. (1998), Multivariate Data Analysis, New Delhi: Pearson Education.

Harris, L. C., \& Goode, M. H. (2004). The four levels of loyalty and pivotal role of trust: A study of online service dynamics. Journal of Retailing, 80(2), 139-158.

doi: http://dx.doi.org/10.1016/j.jretai.2004.04.002 
Hart, S., Smith, A., Sparks, L., \& Tzokas, N. (1999). Are loyalty schemes a manifestations of relationship marketing? Journal of Marketing Management, 15(6), 541-562. doi: http://dx.doi.org/10.1362/026725799785045842

Hocutt. M. A. (1998). Relationship Dissolution model: antecedents of relationship commitment and the liklehood of dissolving a relationship. International Journal of Service Industry Management, 9(2), 189-200. doi: http://dx.doi.org/10.1108/09564239810210541.

Hsieh, Ling-Pie., \& Yeh, Ming-Tsu. (2015). International Journal of Services and Operations Management, 20(1), 21-42. doi: http://dx.doi.org/10.1504/IJSOM.2015.065970

Hsieh, Y.C., Chiu, H.C. \& Chiang, M.Y. (2005). Maintaining a committed online customer: a study across search experience and credence products. Journal of Retailing, 81(1), 75-82. doi: http://dx.doi.org/10.1016/j.jretai.2005.01.006

Jacoby, J. \& Kyner, D. (1973, February). Brand loyalty verses repeat purchase behaviour. Journal of Marketing Research, 1-9. doi: http://dx.doi.org/10.2307/3149402

Jacoby, J. \& Chestnut, R. (1978). Brand loyalty: measurement and management. NewYork, NY John Wiley and Sons.

Jacoby, J. (1971). Brand loyalty: a conceptual definition. Proccedings of the 79th American Psychological Association Convention, 655-656.

Javalgi, R.G., \& Moberg, C. R. (1997). Service Loyalty: Implications for service providers. Journal of Services Marketing, 11(3), 165-179. doi: http://dx.doi.org/10.1108/08876049710168663

Jensen, J. M., \& Hansen, T. (2006). An empirical examination of brand loyalty. Journal of Product \& Brand Management, 15(7), 442-449. doi: http://dx.doi.org/10.1108/10610420610712829

Jones, T. O., \& Sasser, W. (1995). Why satisfied customers defect? Harvard Business Review, 73(6), 88-99.

Jones, M. A., \& Suh, J. (2000). Transaction-specific satisfaction and overall satisfaction: an empirical analysis. Journal of Services Marketing, 14(2), 147-159. doi: http://dx.doi.org/10.1108/08876040010371555

Kabiraj, S. \& Uniyal, D.P. (2013). A qualitative review of approaches for assessing service quality in banking and implications in the Chinese context. Int. J. Qualitative Research in Services, 1(1), 53-75. doi: http://dx.doi.org/10.1504/IJQRS.2013.054363

Kaplan, R. S. \& Nortan, D. P. (1992). The balance scorecard- measures that drive performance. Harvard Business Review, 70(1), 71-79.

Kaur, H., \& Soch, H. (2012). Validating antecedents of consumer loyalty in Indian cell phone users. Vikalpa, 37(1), 47-61. doi: http://www.vikalpa.com/pdf/articles/2012/Pages-from-Vikalpa374-47-61.pdf 
Kosaka, Y., \& Shiizuka, H. (2009). A method for creating buying behavior of customer by kansei information design. Journal of Modelling in Management, 4(1), 19-27. doi: http://dx.doi.org/10.1108/17465660910943739

Krishnamurthi, L., \& Raj, S. P. (1991). An empirical analysis of the relationship between brand loyalty and consumer price elasticity. Marketing Science, 10, 172-183. doi: http://dx.doi.org/10.1287/mksc.10.2.172

Lai, F., Griffin, M., \& Babin, B. (2009). How quality, value, image and satisfaction create loyalty at a Chinese telecom. Journal of Business Research, 62(10), 980-986. doi: http://dx.doi.org/10.1016/j.jbusres.2008.10.015

Ladhari, R., Brun, I., \& Morales, M. (2007). Determinants of Dinning satisfaction and post dinning behavioural intentions. International Journal of Hospitality Management, 27(4), 563-573. doi: http://dx.doi.org/10.1016/j.jhhm.2007.07.025

Lor, P. H., \& George, B. P. (2013). The provision of healthcare services for the Hmong women in the USA: a qualitative inquiry in the Alaskan context. Int. J. Qualitative Research in Services, 1(1), 76-96. doi: http://dx.doi.org/10.1504/IJQRS.2013.054365

McKim, B., \& Hughes, A.M. (2001). How to measure customer relationship management success. Journal of Database Marketing, 8(3), 224-231. doi: http://dx.doi.org/10.1057/palgrave.jdm.3240038

Mellens, M., Dekimpe, M. G., \& Steenkamp, J. B. (1996). A review of brand loyalty measures in marketing. Tijdschriftvoor Economies en management, XLI (4), 507533.

Mithas, S., Krishnan, M. S., \& Fornell, C. (2005). Why do customer relationship management applications affect customer satisfaction? Journal of Marketing, 69(4), 201-209. doi: http://dx.doi.org/10.1509/jmkg.2005.69.4.201

Moornam, C., Delphande', G. \& Zaltman, R. (1993). Factors affecting trust in market research relationships. Journal of Marketing, 57(1), 87-101. doi: http://dx.doi.org/10.2307/1252059

Morgan, M., \& Hunt, D. (1994, July). The commitment-trust theory of relationships marketing. Journal of Marketing, 58(3), 20-38. doi: http://dx.doi.org/10.2307/1252308

Ndubisi, N. O. (2007). Relationship marketing and customer loyalty. Marketing Intelligence and Planning, 25, 1, 98-106. doi: http://dx.doi.org/10.1108/02634500710722425

Ness, J. A., Schroeck, M. L., Letendre, F. R., \& Douglas, W. J. (2002). CRM and customer lifetime value. Cost Management Update, 132, 1-2.

Oliver, R. L. (1980). A cognitive model of antecedents and consequences of satisfaction decisions. Journal of Marketing Research, 17(3), 46-49. 
Oliver, R. L. (1993, December). Cognitive, affective and attribute bases of the satisfaction response. Journal of Consumer Research, 20(3), 418-430. doi: http://dx.doi.org/10.1086/209358

Oliver, R. L. (Special Issue 1999). Whence consumer loyalty? Journal of Marketing, 63, 3344.

Osarenkhoe, A., \& Bennani, A. E. (2007). An exploratory study of implementation of customer relationship management strategy. Business Process Management Journal, 13(1), 139-164. doi: http://dx.doi.org/10.1108/14637150710721177

Oztaysi, B., Sezgin, S., \& Ozak, A. F. (2011). A measurement tool for customer relationship management processes. Industry Management \& Data Systems, 111(6), 943-960. doi: http://dx.doi.org/10.1108/02635571111144982

Pine, B. J II, \& Gilmore, J. (1999). The experience economy: work is theatre \& every business a stage. Bostan, MA: Harvard Business School Press.

Peppers, D., \& Rogers, M. (1993). The One to One future: Building Relationships One Customers at a time. New York: Currency Doubleday.

Ramanathan R. (2012). An exploratory study of marketing, physical and people related performance criteria in hotels. International Journal of Contemporary Hospitality Management, 24(1), 44-61. doi: http://dx.doi.org/10.1108/09596111211197791

Reichheld, F. (2003). The one number you need to grow. Harvard Business Review, 82(12), 46-54.

Richards, K. \& Jones, E. (2008). Customer relationship management: finding value drivers. Industrial Marketing Management, 37(2), 120-130. doi: http://dx.doi.org/10.1016/j.indmarman.2006.08.005

Roberts, M. L., \& Wortzel, L. H. (1979). New life-style determinants of women's food shopping behavior. Journal of Marketing, 43(3), 28-39.

Roest, H., \& Pieters, R. (1997). The nomological net of perceived service quality. The International Journal of Service Industry Management, 8(4), 336-351. doi: http://dx.doi.org/10.1108/09564239710174408

Rundle-Thiele, S. (2005). Elaborating customer loyalty: Exploring loyalty to wine retailers. Journal of Retailing and Consumer Services, 12(5), 333-344. doi: http://dx.doi.org/10.1016/j.jretconser.2004.11.002

Sahin, A., Zehir, C., \& Kitapci, H. (2011). The effects of brand experiences, trust and satisfaction on building brand loyalty; an empirical research on global brands. Procedia Social and Behavioral Sciences, 24, 1288-1301. doi: http://dx.doi.org/10.1016/j.sbspro.2011.09.143

Shankar, R., Vijayaraghavan, P., \& Narendran, T. (2006). Modeling customer support performance in Indian IT hardware industry. Journal of Modelling in Management, 1(3), 232- 254. doi: http://dx.doi.org/10.1108/17465660610715221 
Smith, M., \& Chang, C. (2010). Improving customer outcomes through the implementation of customer relationship management evidence from Taiwan. Asian Review of Accounting, 18(3), 260-285. doi: http://dx.doi.org/10.1108/13217341011089658

Trucker, W.T. (1964). The development of brand loyalty. Journal of Marketing Research, 1(3), 32-35. doi: http://dx.doi.org/10.2307/3150053

Vasumathi, A. \& Subashini, R. (2015), International Journal of Services and Operations Management, 21(3), 370-388. doi: http://dx.doi.org/10.1504/IJSOM.2015.069656

Vlachos A., Samakos, A.T., Vrechopoulos, A., \& Avramidis, P. (2009). Corporate social responsibility: attributions, loyalty and the mediating role of trust. Journal of the Academy of Marketing Science, 37(2), 170-180. doi: http://dx.doi.org/10.1007/s11747-008-0117-x

Vavra, T. (1992). After Marketing: How to Keep Customers for Life through Relationship Marketing. Homewood: Business one Irwin.

Verhoef, P. C., Lemon, K. N., Parasuraman, A., Roggeveen, A., Tsiros, M., \& Schlesinger, L. A. (2009). Customer experience creation: determinants, dynamics and management strategies. Journal of Retailing, 85(1), 31-41. doi:10.1016/j.jretai.2008.11.001

Wang, Y., Lo, H. P., Chi, R., \& Yang, Y. (2004). An integrated framework for customer value and customer-relationship-management performance: a customer based prospective from China. Managing Service Quality, 14(2/3), 169-182. doi: http://dx.doi.org/10.1108/09604520410528590

Wetzels, M., Ruyter Ko De., \& Brigelen, M.V. (1998). Marketing Service Relationships: Trole of commitment. Journal of Business and Industrial Marketing, 13(4/5), 406423. doi: http://dx.doi.org/10.1108/08858629810226708

Wrestbook, R.A. \& Oliver, R.L. (1991). The dimensionality of consumption emotion patterns and consumer satisfaction. Journal of Consumer Research, 18, 84-91. doi: http://www.jstor.org/stable/2489487

Wu, Li-Wei. (2011). Satisfaction, inertia, and customer loyalty in the varying levels of the zone of tolerance and alternative attractiveness. Journal of Services Marketing, 25(5), 310-322. doi: http://dx.doi.org/10.1108/08876041111149676

Yannis, P., Giovanis, A., \& Binioris, S. (2014). Logistics service quality and its effects on customer satisfaction in the manufacturing companies' supply chains: Empirical evidence from Greece. Journal of Modelling in Management, 9(2), 215-237. doi: http://dx.doi.org/10.1108/JM2-05-2012-0016

Yu, Y. T., \& Dean, A. (2001). The contribution of emotional satisfaction to consumer loyalty. International Journal of Service Industry Management, 12(3), 234-240. doi: http://dx.doi.org/10.1108/09564230110393239 
Zablah, A. R., Bellenger, D. N., \& Johnston, W. J. (2004). An evaluation of divergent perspectives on customer relationship management: towards a common understanding of an emerging phenomenon. Industrial Marketing Management, 33, 475-489. doi: http://dx.doi.org/10.1016/j.indmarman.2004.01.006

Zeithaml, V.A., Berry, L.L., \& Parasuraman, A. (1996). The behavioral consequences of service quality. Journal of Marketing, 60(2), 31-46. doi:

http://dx.doi.org/10.2307/1251929

Zineldin, M. (2006). The royalty of loyalty: CRM, quality and retention. Journal of Consumer Marketing, 23(7), 430-437. doi:

http://dx.doi.org/10.1108/07363760610712975 


\section{Appendices}

Table 01: Sample Profile

\begin{tabular}{|c|c|c|c|c|}
\hline \multirow[t]{2}{*}{ Factor } & & \multicolumn{3}{|c|}{ Percent (\%) } \\
\hline & & Health & Retail & Wellness \\
\hline \multirow[t]{3}{*}{ Gender } & Male & 42 & 55 & 45 \\
\hline & Female & 58 & 45 & 55 \\
\hline & Total & 100 & 100 & 100 \\
\hline \multirow[t]{5}{*}{ Age (Years) } & Up to 25 & 38.5 & 33 & 48 \\
\hline & $26-40$ & 26.5 & 16 & 25 \\
\hline & $41-55$ & 14 & 36 & 12 \\
\hline & Above 55 & 21 & 15 & 15 \\
\hline & Total & 100 & 100 & 100 \\
\hline \multirow[t]{5}{*}{ Income (Rs.) } & Less than 180000 & 9 & 12.5 & 14 \\
\hline & $180001-500000$ & 45 & 46.5 & 58.5 \\
\hline & $500001-800000$ & 37 & 22.5 & 20.5 \\
\hline & More than 800000 & 9 & 18.5 & 7 \\
\hline & Total & 100 & 100 & 100 \\
\hline \multirow[t]{5}{*}{ Education } & Less than Graduation & 2.5 & 4 & 8 \\
\hline & Graduation & 54.5 & 55.5 & 54 \\
\hline & Post-graduation & 17 & 17.5 & 26 \\
\hline & Professional degree & 26 & 23 & 12 \\
\hline & Total & 100 & 100 & 100 \\
\hline
\end{tabular}


Table 02: CFA Results in Health, Retail, and Wellness

\begin{tabular}{|c|c|c|c|c|c|}
\hline \multirow{2}{*}{ Construct } & \multirow{2}{*}{$\begin{array}{l}\text { Item } \\
\text { label }\end{array}$} & \multirow{2}{*}{ Statement Description } & Health & Retail & Wellness \\
\hline & & & $\begin{array}{l}\text { Critical } \\
\text { Ratio }\end{array}$ & $\begin{array}{l}\text { Critical } \\
\text { Ratio }\end{array}$ & $\begin{array}{l}\text { Critical } \\
\text { Ratio }\end{array}$ \\
\hline \multirow{15}{*}{$\begin{array}{l}\text { Consumer } \\
\text { Acquisition } \\
\text { Efforts (CA) }\end{array}$} & CA1 & Service Quality & $* *$ & $* *$ & $* *$ \\
\hline & CA2 & Customized services & 8.981 & 7.14 & 17.761 \\
\hline & CA3 & Wide-Variety & 7.34 & 9.769 & 10.531 \\
\hline & CA4 & Partnerships with Other Firms & 7.913 & 8.391 & 5.507 \\
\hline & CA5 & Reasonable Price & 4.981 & 11.156 & 9.984 \\
\hline & CA6 & Nearby locations & 9.001 & 7.595 & 10.197 \\
\hline & CA7 & Advertisement's Reliability & 0.18 & 0.89 & 0.37 \\
\hline & CA8 & $\begin{array}{l}\text { Emotional Response to } \\
\text { Advertisement }\end{array}$ & 7.327 & 7.775 & 6.132 \\
\hline & CA9 & Price Discounts and Other Benefits & 6.16 & 9.278 & 5.038 \\
\hline & CA10 & Well-known Image & 8.827 & 8.408 & 11.385 \\
\hline & CA11* & Contact by Awareness Camps & 6.553 & 5.604 & 0.56 \\
\hline & CA12 & Skilled \& Expertize Services & 7.79 & 1.573 & 5.361 \\
\hline & CA13* & Contact by Recommendations & 2.811 & 1.372 & 9.302 \\
\hline & CA14 & Contact by Emails and SMSs & 7.786 & 4.777 & 5.929 \\
\hline & CA15 & $\begin{array}{l}\text { Contact by Automated and Manual } \\
\text { Calls }\end{array}$ & 6.297 & 1.058 & 1.269 \\
\hline \multirow[t]{5}{*}{ Satisfaction (S) } & S1 & $\begin{array}{l}\text { Cognitive Satisfaction in terms of } \\
\text { Performance }\end{array}$ & $* *$ & $* *$ & $* *$ \\
\hline & S2 & $\begin{array}{l}\text { Cognitive Satisfaction in terms of } \\
\text { Staff's Competence }\end{array}$ & 17.049 & 13.941 & 14.213 \\
\hline & S3 & Emotional Satisfaction & 16.996 & 14.576 & 14.326 \\
\hline & S4 & Overall Satisfaction & 16.209 & 13.925 & 13.872 \\
\hline & S5 & Relative Satisfaction & 15.427 & 12.517 & 13.084 \\
\hline \multirow[t]{5}{*}{ Trust (T) } & $\mathrm{T} 1$ & Confidence to get Consistent Quality & $* *$ & $* *$ & $* *$ \\
\hline & $\mathrm{T} 2$ & Confidence to get Caring Attitude & 19.452 & 10.999 & 15.138 \\
\hline & $\mathrm{T} 3$ & Reliable Staff & 18.246 & 11.005 & 15.650 \\
\hline & $\mathrm{T} 4$ & Reliable for Future Dealings & 16.826 & 11.737 & 13.136 \\
\hline & $\mathrm{T} 5$ & Positive Future Intentions & 14.883 & 10.968 & 12.384 \\
\hline
\end{tabular}




\begin{tabular}{|l|l|l|l|l|l|}
\hline $\begin{array}{l}\text { Commitment } \\
(\mathbf{C})\end{array}$ & C1 & Sacrifices based Commitment & 9.275 & 7.171 & 9.433 \\
\hline & C2 & Continuance Commitment & 0.653 & 0.483 & 4.003 \\
\hline & C3 & Sense of Belongingness & 7.812 & 7.058 & 9.989 \\
\hline & C4 & Being a Proud Consumer & 10.354 & 7.297 & 10.787 \\
\hline & C5 & Positive to Firm's Growth & 14.166 & 7.281 & 9.158 \\
\hline & C6 & Mutual Trust Based Commitment & $* *$ & $* *$ & $* *$ \\
\hline $\begin{array}{l}\text { Attitudinal } \\
\text { Loyalty (AL) }\end{array}$ & AL1 & Word of Mouth Publicity & $* *$ & $* *$ & $* *$ \\
\hline & AL2 & Recommendations to Others & 10.954 & 9.464 & 12.183 \\
\hline & AL3 & Willingness to be a Loyal Consumer & 12.211 & 9.422 & 11.95 \\
\hline & AL4 & First Choice & 12.156 & 8.598 & 12.211 \\
\hline & AL5 & $\begin{array}{l}\text { Ignorance to other Seller } \\
\text { Commercials }\end{array}$ & 11.907 & 8.575 & 12.361 \\
\hline & AL6 & $\begin{array}{l}\text { To Understand the Reasons of } \\
\text { Preference }\end{array}$ & 10.484 & 7.278 & 12.235 \\
\hline & BL1 & Frequent Buyer & $* *$ & $* *$ & $* *$ \\
\hline Behavioral \\
\hline
\end{tabular}

\section{Notes:}

Source: Values of critical ratios extracted from CFA-AMOS modeling output results

Critical ratios are t- values. Critical ratio above 1.96 found to be significant at the $5 \%$ level of significance.

*reverse scored items

** Parameter fixed at 1.0 in the Amos measurement model. 
Table 03: Reliability and Validity Indexes

\begin{tabular}{|c|c|c|c|c|c|c|c|c|c|}
\hline \multirow[b]{2}{*}{ Constructs } & \multicolumn{3}{|c|}{ Health } & \multicolumn{3}{|c|}{ Retail } & \multicolumn{3}{|c|}{ Wellness } \\
\hline & 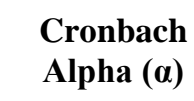 & $\begin{array}{l}\text { Composite } \\
\text { Reliability }\end{array}$ & AVE* & 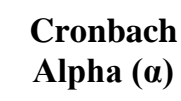 & $\begin{array}{l}\text { Composite } \\
\text { Reliability }\end{array}$ & AVE* & $\begin{array}{l}\text { Cronbach } \\
\text { Alpha }(\alpha)\end{array}$ & $\begin{array}{l}\text { Composite } \\
\text { Reliability }\end{array}$ & AVE* \\
\hline $\begin{array}{l}\text { Consumer } \\
\text { Acquisition } \\
\text { Efforts }\end{array}$ & 0.8 & 0.8 & 0.5 & 0.8 & 0.8 & 0.5 & 0.8 & 0.8 & 0.5 \\
\hline Satisfaction & 0.9 & 0.9 & 0.9 & 0.9 & 0.9 & 0.9 & 0.9 & 0.9 & 0.9 \\
\hline Trust & 0.9 & 0.9 & 0.9 & 0.9 & 0.9 & 0.8 & 0.9 & 0.9 & 0.8 \\
\hline Commitment & 0.7 & 0.8 & 0.6 & 0.8 & 0.8 & 0.6 & 0.8 & 0.7 & 0.7 \\
\hline $\begin{array}{l}\text { Attitudinal } \\
\text { loyalty }\end{array}$ & 0.9 & 0.9 & 0.8 & 0.9 & 0.9 & 0.7 & 0.9 & 0.9 & 0.8 \\
\hline $\begin{array}{l}\text { Behavioral } \\
\text { Loyalty }\end{array}$ & 0.8 & 0.8 & 0.7 & 0.8 & 0.8 & 0.7 & 0.8 & 0.8 & 0.7 \\
\hline
\end{tabular}

*AVE: Average Variance Extracted 
Table 04: Models Measuring Invariances across Three Samples

\begin{tabular}{|l|l|l|l|l|l|l|l|}
\hline S. No. & \multicolumn{1}{|c|}{ Models } & CIMIN/DF & RMSEA & PCFI & $\begin{array}{c}\text { Nested } \\
\text { Model }\end{array}$ & $\begin{array}{c}\text { Chi-square } \\
\text { difference }\end{array}$ & Assessment \\
\hline 1 & Base Model & 1.808 & .037 & .687 & & & \\
\hline 2 & Equal Loading Model & 1.851 & .038 & .670 & $2-1$ & $.043^{*}$ & Not Significant \\
\hline 3 & Structural weights & 2.058 & .042 & .606 & $3-2$ & $.207^{*}$ & Not Significant \\
\hline 4 & Measurement Residuals & 2.084 & .043 & .595 & $4-3$ & $.026^{*}$ & Not Significant \\
\hline
\end{tabular}

Source: Values extracted from Amos output

${ }^{*}$ Chi-square difference tested at $5 \%$ level. 
Table 05: SEM Results of Proposed Hypotheses

\begin{tabular}{|l|l|l|l|l|l|l|l|}
\hline \multirow{2}{*}{} & \multicolumn{2}{|c|}{ Health } & \multicolumn{2}{c|}{ Retail } & \multicolumn{2}{c|}{ Wellness } \\
\hline $\begin{array}{c}\text { Proposed } \\
\text { Hypothesis }\end{array}$ & $\begin{array}{c}\text { Proposed } \\
\text { Relationships }\end{array}$ & $\begin{array}{c}\text { Critical } \\
\text { Ratio }\end{array}$ & Assessment & $\begin{array}{c}\text { Critical } \\
\text { Ratio }\end{array}$ & Assessment & $\begin{array}{c}\text { Critical } \\
\text { Ratio }\end{array}$ & Assessment \\
\hline H1 & CA $\rightarrow \mathrm{S}$ & $2.239^{*}$ & accepted & $3.277^{*}$ & accepted & $2.251^{*}$ & accepted \\
\hline H2 & CA $\rightarrow \mathrm{T}$ & 0.442 & rejected & 1.051 & rejected & 0.395 & rejected \\
\hline H3 & CA $\rightarrow$ C & 1.105 & rejected & 0.823 & rejected & 1.459 & rejected \\
\hline H4 & $\mathrm{S} \rightarrow \mathrm{AL}$ & 1.123 & rejected & 0.770 & rejected & 0.701 & rejected \\
\hline H5 & $\mathrm{S} \rightarrow \mathrm{BL}$ & $2.220^{*}$ & accepted & -0.70 & rejected & $2.527^{*}$ & accepted \\
\hline H6 & $\mathrm{T} \rightarrow \mathrm{AL}$ & $4.230^{*}$ & accepted & $4.256^{*}$ & accepted & $4.230^{*}$ & accepted \\
\hline H7 & $\mathrm{T} \rightarrow \mathrm{BL}$ & -0.347 & rejected & 0.594 & rejected & -0.12 & rejected \\
\hline H8 & $\mathrm{C} \rightarrow \mathrm{AL}$ & $3.594^{*}$ & accepted & $2.813^{*}$ & accepted & $3.105^{*}$ & accepted \\
\hline H9 & $\mathrm{C} \rightarrow \mathrm{BL}$ & $2.269^{*}$ & accepted & $2.232^{*}$ & accepted & $2.226^{*}$ & accepted \\
\hline H10 & $\mathrm{CA} \rightarrow \mathrm{AL}$ & 1.033 & rejected & 0.148 & rejected & -0.371 & rejected \\
\hline H11 & $\mathrm{CA} \rightarrow \mathrm{BL}$ & -0.163 & rejected & 0.937 & rejected & -0.475 & rejected \\
\hline
\end{tabular}

Note: Values extracted from Amos output

Critical Ratios extracted from AMOS output.

* Significant at $5 \%$ level of significance 


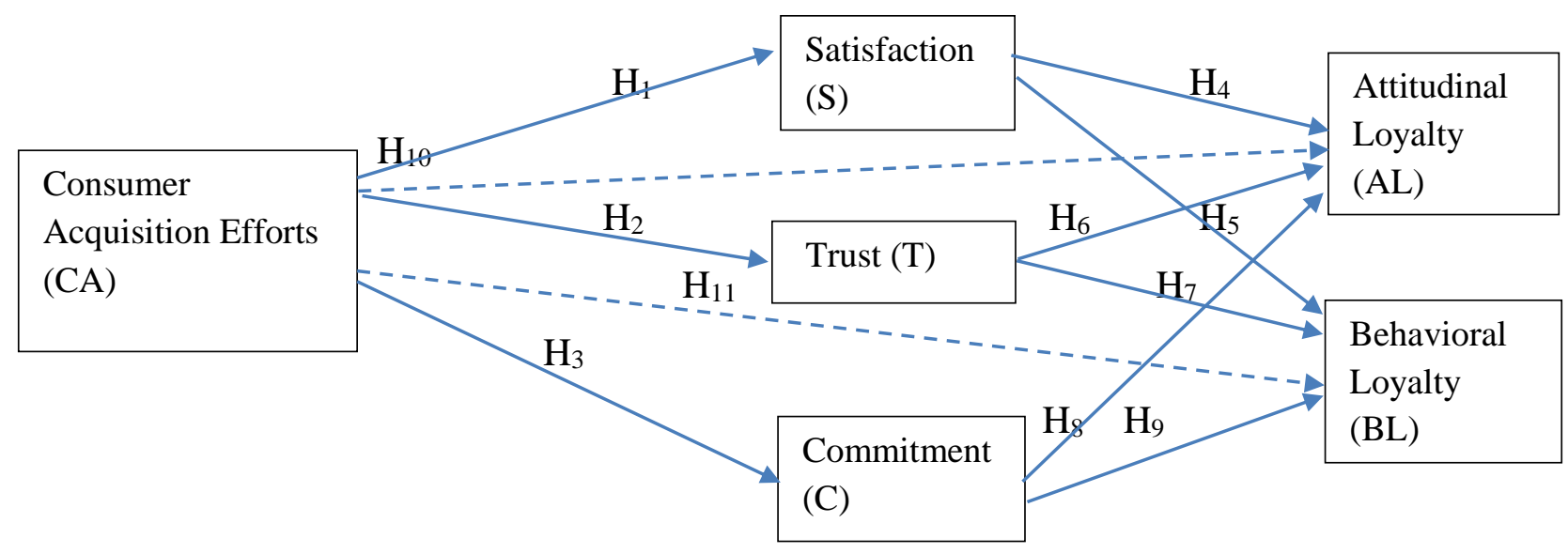

Note: $\longrightarrow$ Indicates indirect relationships between Consumer Acquisition Efforts and two forms of CL. $\rightarrow$ Indicates direct relationships between Consumer Acquisition Efforts and two forms of CL.

\section{Figure 01: Proposed Theoretical Model with Hypotheses}




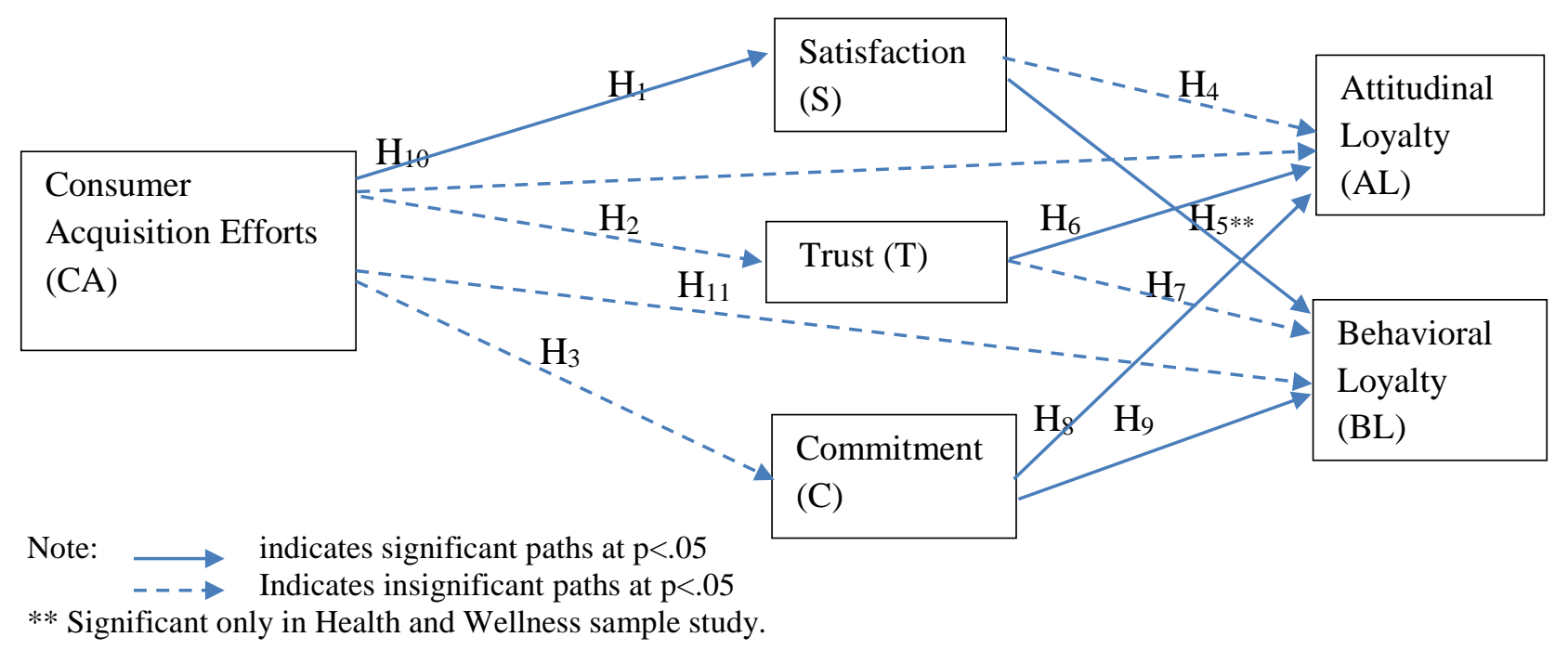

Figure 02: Structural Model showing Acceptance and Rejection of Proposed Hypotheses 